\title{
Perkembangan Sosial Islam di Filipina
}

\author{
Hasaruddin \\ Universitas Islam Negeri Alauddin, Makassar, 92113, Indonesia \\ *email: hasaruddin@gmail.com
}

\begin{abstract}
Abstrak
Filipina merupakan salah satu Negara yang terdapat di Asia Tenggara yang mayoritas penduduknya beragama Katolik. Islam menjadi agama minoritas. Meskipun Islam menjadi minoritas, terdapat wilayah yang menjadikan Islam sebagai agama mayoritas yaitu di Filipina bagian Selatan. Proses islamisasi di Filipina pada masa awal adalah melalui tiga hal, yaitu: perdagangan, perkawinan, dan politik. Diterimanya Islam oleh orang-orang Mindanao, Sulu, Manilad dan sepanjang pesisir pantai kepulauan Filipina tidak terlepas dari ajaran Islam yang dibawa oleh para pedagang tersebut dapat mengakomodasi tradisi lokal. Umat Islam Filipina yang kemudian dikenal dengan bangsa Moro, pada akhirnya menghadapi berbagai hambatan baik pada masa kolonial maupun pasca kemerdekaan. Bila direntang ke belakang, perjuangan bangsa Moro dapat dibagi menjadi tiga fase, yaitu: Moro berjuang melawan penguasa Spanyol selama lebih dari 375 tahun (1521-1898), Moro berusaha bebas dari kolonialisme Amerika selama 47 tahun (1898-1946), dan Moro melawan pemerintah Filipina (1970sekarang).
\end{abstract}

Kata Kunci: Filipina, Islam, Sejarah

\begin{abstract}
Abstact
The Philippines is one of the countries in Southeast Asia where the majority of the population is Catholic. Islam is a minority religion. Even though Islam is a minority, there are areas that make Islam the majority religion, namely in the southern Philippines. The process of Islamization in the Philippines in the early days was through three things, namely: trade, marriage and politics. The acceptance of Islam by the people of Mindanao, Sulu, Manilad and along the coast of the Philippine archipelago was inseparable from the Islamic teachings brought by these traders to accommodate local traditions. The Filipino Muslims, who became known as the Moro people, in the end faced various obstacles both during the colonial and post-independence period. If stretched backward, the struggle of the Moro nation can be divided into three phases, namely: Moro fought against the Spanish rulers for more than 375 years (1521-1898), Moro tried to be free from American colonialism for 47 years (1898-1946), and Moro fought back. Philippine government (1970-present).
\end{abstract}

Keywords: History, Islam, Philippines 


\section{Pendahuluan}

Menurut Azyumardi Azra bahwa kawasan Asia Tenggara terbagi menjadi tiga bagian berdasarkan atas pengaruh yang diterima wilayah tersebut. Pertama adalah wilayah Indianized Southeast Asia, Asia Tenggara yang dipengaruhi India yang dalam hal ini hindu dan budha. Kedua, Sinized South East Asia, wilayah yang mendapatkan pengaruh China, adalah Vietnam. Ketiga, yaitu wilayah Asia Tenggara yang dispanyolkan, atau Hispainized South East Asia, yaitu Philipina. Ketiga pembagian tersebut seolah meniadakan pengaruh Islam yang begitu besar di Asia Tenggara, khususnya Philipina. Seperti tertulis bahwa Philipina termasuk negara yang terpengaruhi oleh Spanyol. Hal itu benar adanya, akan tetapi pranata kehidupan di Philipina juga terpengaruhi oleh Islam pada masa penjajahan amerika dan spanyol. Makalah ini akan menyingkap dengan singkat tentang sejarah masuknya Islam di Philipina.

Islam di Asia menurut Dr. Hamid dalam bukunya yang berjudul "Islam Sebagai Kekuatan International", Dr. Hamid mencantumkan bahwa Islam di Philipina merupakan salah satu kelompok minoritas diantara negara-negara yang lain. Dari statistik demografi pada tahun 1977, masyarakat Philipina berjumlah 44. 300.000 jiwa. Sedangkan jumlah masyarakat Muslim 2.348.000 jiwa. Dengan prosentase 5,3\% dengan unsur dominan komunitas Mindanao dan mogondinao.

Asia tenggara adalah sebutan untuk wialyah daratan Asia bagian timur yang terdiri dari jazirah Indo-Cina dan kepualauan yang banyak serta terilingkupi dalam Negara Indonesia dan Philipina. Melihat sejarah masa lalu, terlihat bahwa Islam bukanlah agama pertama yang tumbuh pesat, akan tetapi Islam masuk ke lapisan masyarakat yang waktu itu telah memiliki peradaban, budaya, dan agama.

Dalam makalah ini, pemakalah akan membahas beberapa hal penting tentang Islam di Filipina. Antara lain: Sejarah masuknya Islam di Filipina, faktor-faktor Islam menjadi agama minoritas di Filipina. Hal-hal tersebut menjadi pembahasan dalam makalah ini, karena merupakan sebuah upaya besar dalam mengangkat dan menyebarkan agama Islam.

Dari latar belakang di atas, penulis mengemukakan permasalahan sebagai pokok pembahasan dalam makalah ini. Bagaimana sejarah masuknya Islam di Filipina? Bagaimana perkembangan Peradaban Islam di Filipina?

\section{Pembahasan}

\section{Kondisi Geografis Filipina}

Filipina adalah sebuah negara Republik dengan luas wilayah 114.830 mil dengan jumlah penduduk 49.139.350 jiwa. Dilihat dari luas wilayahnya, maka Filipina tidaklah termasuk negara padat penduduk. Mayoritas penduduknya beragama Katolik yaitu, $85,8 \%$ dari keseluruhan jumlah penduduk. Islam 4\%, Protestan 3,1\%, Iglesiani Kristo $1,3 \%$, Budhis $0,08 \%$, dan lain-lain $20 \%$. Iklim daerah Filipina adalah tropis yang hampir sama dengan semua yang terjadi di Asia Tenggara, namun Filipina mempunyai temperatur panas yang tinggi dan kurang berawan.

Dr. Hamid dalam bukunya "Islam Sebagai Kekuatan International", mencantumkan bahwa Islam di Philipina merupakan salah satu kelompok minoritas diantara negara-negara yang lain. Dari statistik demografi pada tahun 1977, Masyarakat Philipina berjumlah 44. 300.000 jiwa. Sedangkan jumlah masyarakat Muslim 2.348.000 
jiwa. Dengan prosentase 5,3\% dengan unsur dominan komunitas Mindanao dan Mogondinao.

Kedaulatan Filipina diperoleh pada tanggal 4 Juli 1946 didasarkan UndangUndang 1935. Bahasa Nasional Filipina adalah "Philipino" yang pada dasarnya diambil dari bahasa "Tagalog" yang banyak digunakan oleh masyarakat di Manila dan sekitarnya. Ada 87 banyaknya dialek bahasa, hal ini mencerminkan banyaknya suku dan etnis. Mata uangnya adalah Peso terdiri dari kertas dan logam.

\section{Sejarah Masuknya Islam di Filipina}

Sejarah masuknya Islam di Filipina tidak dapat dilepaskan dari kondisi sosiocultural wilayah tersebut sebelum kedatangan Islam. Filipina adalah sebuah Negara kepulauan yang terdiri dari 7107 pulau. Penduduknya yang berjumlah 47 jiwa menggunakan 87 dialek bahasa yang berbeda yang mencerminkan banyaknya suku dan komunitas etnis. Sebelum kedatangan Islam, Filipina adalah sebuah wilayah yang dikuasai oleh kerajaan-kerajaan. Islam dapat masuk dan diterima dengan baik oleh penduduk setempat setidaknya karena ajaran Islam dapat mengakomodasi berbagai tradisi yang telah mereka lakukan selama ini.

Para ahli sejarah menemukan bukti abad ke-16 dan abad ke-17 dari sumbersumber Spanyol tentang keyakinan agama penduduk Asia Tenggara termasuk Luzon, yang merupakan bagian dari Negara Filipina saat ini, sebelum kedatangan Islam. Sumber-sumber tersebut memberikan penjelasan bahwa sistem keyakinan agama yang sangat dominan ketika Islam datang pada abad ke-14 syarat berbagai upacara pemujaan untuk orang yang sudah meninggal.

Hal ini jelas sekali tidak sejalan dengan ajaran Islam yang menentang keras penyembahan berhala dan politeisme. Namun tampaknya Islam dapat memperlihatkan kepada mereka bahwa agama ini memiliki cara tersendiri yang menjamin arwah orang yang meninggal dunia berada dalam keadaan tenang, yang ternyata dapat mereka terima.

Islam masuk ke wilayah Filipina Selatan, khususnya kepulauan Sulu dan Mindanao pada tahun 1380 M. Seorang tabib dan ulama Arab bernama Karimul Makhdum dan Raja Baguinda tercatat sebagai orang pertama yang menyebarkan ajaran Islam di kepulauan tersebut. Menurut catatan sejarah, Raja Baguinda adalah seorang pangeran dari Minangkabau (Sumatra Barat). Ia tiba di kepulauan Sulu sepuluh tahun setelah berhasil mendakwahkan Islam di kepulauan Zamboanga dan Basilan. Atas hasil kerja kerasnya juga, akhirnya Kabungsuwan Manguindanao, raja terkenal dari Manguindanao memeluk Islam. Dari sinilah awal peradaban Islam di wilayah ini mulai dirintis. Adapula pendapat yang lain mengenai masuknya Islam datang ke kepulaun Sulu. Bahwasannya Islam datang ke Sulu pada abad ke-9 melalui perdagangan. Tapi itu tidak menjadi faktor yang penting dalam sejarah Sulu, sampai abad ke 13 ketika orangorang menyebarkan Islam (da'i) mulai pertama kali tinggal di Buasna (Jolo) kemudian di daerah-daerah lain kepulauan Sulu.

Islam di asia menurut Dr. Hamid mempunyai 3 bentuk penyebaran. Pertama, penyebaran Islam melahirkan mayoritas penduduk. Kedua, kelompok minoritas Islam. Ketiga, kelompok negera-negara Islam tertindas.

Dalam bukunya yang berjudul Islam Sebagai Kekuatan International, Dr. Hamid mencantumkan bahwa Islam di Philipina merukan salah satu kelompok ninoritas diantara negara-negara yang lain. Dari statistik demografi pada tahun 1977, Masyarakat Philipina berjumlah 44.300.000 jiwa. Sedangkan jumlah masyarakat Muslim 2.348.000 
jiwa. Dengan prosentase 5,3\% dengan unsur dominan komunitas Mindanao dan Mogondinao.

Hal itu pastinya tidak lepas dari sejarah latar belakang Islam di negeri Philipina. Bahkan lebih dari itu, bukan hanya penjajahan saja, akan tetapi konflik internal yang masih berlanjut sampai saat ini.

Sejarah masuknya Islam ke wilayah Filipina Selatan, khususnya kepulauan Sulu dan Mindanao pada tahun 1380 M., seorang tabib dan ulama Arab bernama Karimul Makhdum dan Raja Baguinda tercatat sebagai orang pertama yang menyebarkan ajaran Islam di kepulauan tersebut. Menurut catatan sejarah, Raja Baguinda adalah seorang pangeran dari Minangkabau (Sumatra Barat). Ia tiba di kepulauan Sulu sepuluh tahun setelah berhasil mendakwahkan Islam di kepulauan Zamboanga dan Basilan. Atas hasil kerja kerasnya juga, akhirnya Kabungsuwan Manguindanao, raja terkenal dari Manguindanao memeluk Islam. Dari sinilah awal peradaban Islam di wilayah ini mulai dirintis. Pada masa itu, sudah dikenal sistem pemerintahan dan peraturan hukum yaitu Manguindanao Code of Law atau Luwaran yang didasarkan atas Minhaj dan Fathu-iQareeb, Taqreebu-i-Intifa dan Mir-atu-Thullab. Manguindanao kemudian menjadi seorang Datuk yang berkuasa di profinsi Davao di bagian tenggara pulau Mindanao. Setelah itu, Islam disebarkan ke pulau Lanao dan bagian utara Zamboanga serta daerah pantai lainnya. Sepanjang garis pantai kepulauan Filipina semuanya berada di bawah kekuasaan pemimpin-pemimpin Islam yang bergelar Datuk atau Raja. Menurut ahli sejarah kata Manila (Ibukota Filipina sekarang) berasal dari kata Amanullah (negeri Allah yang aman). Pendapat ini bisa jadi benar, mengingat kalimat tersebut banyak digunakan oleh masyarakat sub-kontinen.

Sejarah masuknya Islam di Filipina dimulai pada abad ke-14 melalui kepulauan Sulu. Disebutkan bahwa orang yang sangat berjasa dalam penyebaran Islam pertama di kepulaan tersebut adalah Syarif Karim al-Makhdum, ia adalah orang Arab yang datang ke Malaka dan mengislamkan Sultan Muhammad Syah dan rakyat Malaka. Setelah beberapa lama menetap, ia kemudian melanjutkan perjalanan ke Timur dan tiba di Sulu sekitar tahun 1380 dan menetap di Bwansa, ibu kota Sulu yang lama, di sana alMakhdum bersama penduduk setempat membangun sebuah masjid sebagai sentral kegiatan dakwah, hasil dari usaha tersebut cukup menggembirakan karena banyak pemimpin-pemimpin lokal yang tertarik menerima ajarannya. Muballigh lainnya yang patut disebutkan kerena jasanya dalam penyebaran Islam di Filipina yakni Abu Bakar, ia juga seorang Arab yang memulai tugas dakwahnya di Malaka, Palembang, Brunei dan akhirnya sampai di Sulu sekitar tahun 1450.

Setelah tiba di Kepulaun tersebut dan merasa telah cukup pengikutnyanya ia pun mendirikan masjid sebagaimana pendahulunya sehingga kegitan dakwahnya berkembang, puncak kesuksesannya ketika Raja Bwansa, Raja Baginda menjadikannya menantu dan ahli waris kerajaan. Abu Bakar pun kemudian menjadi Sultan dengan gelar Sharif al-Hashim, ia dianggap peletak dasar kesultanan Sulu dan cikal bakal dari sultansultan dan datu-datu di kepulauan tersebut. Bersamaan dengan datangnya Abu Bakar ke Sulu, di tempat lain juga telah datang para muballigh yang berdarah Arab ke Mangindanao, merekalah yang mula-mula yang membuntuk tatanan masyarakat Islam di sana. Sementara abad ke-16, datang Syarif Muhammad Kabungsuan yang konon adalah seorang pangeran dari Johor bersama pengikutnya, seperti halnya Abu Bakar, Kabungsuan tidak hanya melanjutkan proses Islamisasi, tetapi lebih penting adalah meletakkan dasar kesultanan Maguindanao. Ia sering disebut dalam silsilah raja-raja sebagai orang satu-satunya yang bertanggungjawab dalam Islamisasi Mindanao. 
Data historis tersebut di atas, menunjukkan kuatnya pendapat yang mengatakan bahwa Islam datang ke Asia Tenggara langsung dari Arab termasuk wilayah Filipina, atau tepatnya dari Hadramaut. Dari seluruh tokoh yang berjasa dalam penyebaran Islam di Filipina, mereka adalah berasal dari Arab dengan gelar Syarif atau Sayyid. Alasan lain yang memperkuat tesis yang mengatakan Islam datang ke Asia Tenggara berasal dari Hadramaut walau sifatnya lebih umum yaitu adanya kesamaan mazhab yang dianut pada semua tempat di Asia Tenggara yakni mazhab Syafi'i.

Dakwah Islam terus berlangsung sampai tersebar ke hampir keseluruh Filipina termasuk di kota Manila, hanya saja penyebarannya terhenti ketika orang-orang Spanyol datang dibawah Agustin de Lagasapi sekitar 1565, maka sejak itu pula Filipina dijajah sekaligus dijadikan lahan penyebarkan agama Kristen Katolik. Namun penguasaan penjajah tersebut tidak berhasil menduduki semua daerah dalam wilayah Filipina, kesultanan Islam di Mindanau dan Sulu berhasil mempertahankan diri dari serangan Portugis dari arah Selatan. Tahun 1898, karena sesuatu hal Spanyol harus menyerahkan kekuasaan kepada Amerika, Selama pendudukan tersebut kesultanan Mindanao dan Sulu dapat disatukan pada tahun 1903. Sedangkan secara administratif kedua wilyah itu baru diakui oleh pemerintahan Filipina tahun 1914-1920. Suatu hal yang menarik disimak, masyarakat muslim Filipina tidak banyak terpengaruh dengan penetrasi kolonialisme, meskipun ia termasuk negara di Asia Tenggara yang paling lama dijajah, bahwa umat Islam Filipina tetap tidak pernah mengikuti keinginan penjajah, dalam artian bahwa masyarakat muslim Filipina sangat kuat memegang tradisinya, ulet dalam memperjuangkan dan mempertahankan kebebasannya (terkontekstualisasi pemikiran keagamaannya).

\section{Perkembangan Islam di Filipina}

Kebangkitan Islam terus digaungkan oleh dua kelompok yang sama-sama mengatasnamakan umat Islam Filipina. Kelompok pertama berpandangan radikal, dipegang oleh para anggota Moro National Liberation Front (MNLF) yang merupakan minoritas di kalangan penduduk muslim. Kelompok kedua berpandangan moderat, dipegang oleh warga Muslim yang ingin memprakarsai berbagai perubahan dalam masyarakat yang lebih luas. Kelompok moderat yang didukung oleh mayoritas penduduk berusaha mempertahankan diri sebagai masyarakat Muslim. Mereka mau masuk ke dalam sistem politik Filipina demi mencapai tujuan-tujuan mereka, dengan menggunakan semua cara-cara legal dan konstitusional yang ada, termasuk penyebarluasan ide-ide pemikiran, mengorganisir kelompok-kelompok penekan dan berpartisipasi dalam usaha-usaha pemerintah untuk menemukan suatu penyelesaian yang damai adil terhadap Moro.

Moro National Liberation Front (MNLF) menggunakan dua strategi yakni menarik perhatian internasional, khususnya negara-negara Islam - tentang nasib mereka yang tertindas; menjalankan perang gerilya untuk melemahkan Pemerintah Filipina.

Suasana dan posisi umat Islam di Pilifina mempengaruhi strategi dan keberlangsungan kegiatan dakwah. Sebuah organisasi Islam yang berskala Filipina adalah CONVISLAM atau "Converst to Islam", yang didirikan pada tahun 1954 secara aktif bergerak untuk kegiatan dakwah. Pada tahun 1981, Convislam mempelopori sebuah organisasi dakwah yang berskala nasional yang disebut Islamic Da'wah Council of the Philippines, Inc (Majlis al-Da'wah al-Islamiyyah al-Philipiniyyah) untuk menjadi payung semua gerakan dan kegiatan dakwah. Kegiatan-kegiatannya antara lain penerbitan buku-buku Islam, kunjungan ke cabang-cabang provinsi, menyelenggarakan 
serangkaian kuliah umum, membangun masjid, menghadiri konferensi-konferensi internasional dan program-program pelatihan untuk usaha dakwah Islam, menyelenggarakan sekolah minggu dan kursus-kursus bahasa Arab. Di samping itu, terdapat banyak sekolah madrasah yang didirikan oleh organisasi-organisasi Muslim terutama di provinsi-provinsi bagian selatan.

Kemudian seorang tokoh terkenal Muslim Filipina, Peter Gordon Gowing, juga menyebutkan kelompok dakwah seperti tableegh Marawi City. Mereka ini adalah Shubba'anol Muslimeen Tableegh of Philippenes, Jama'at Tableegh, dan Islamic Tableegh of the Philippines. Organisasi-organisasi ini sedikit yang dapat diketahui karena kurangnya informasi yang lebih jauh mengenai eksistensi dan kegiatannya, kendati dari sisi distribusi keanggotaannya cukup luas. Hal yang tidak dapat dilewatkan mengenai organisasi-organisasi yang erat kaitannya dengan kebangkitan Islam di Filipina walaupun sangat terkait dengan posisi tawar -menawar antara umat Islam secara umum dengan pemerintah antara lain lahirnya Peranan Kementerian Urusan Muslim, yang antara lain bertugas menyelenggarakan ibadat haji. Demikian pula Bank Amanah, sebuah bank Muslim yang berhubungan dengan kementerian, dan secra khusus didirikan untuk melaksanakan ketentuan Islam mengenai larangan riba. Didirikannya bank semacam ini sungguh merupakan suatu prestasi.

Secara umum gambaran masuknya Islam di Philiphina melalui beberapa fase, dari penjajahan sampai masa modern.

\section{Masa Kolonial Spanyol}

Proses Islamisasi di seluruh Filipina secara tiba-tiba terhenti akibat datangnya bangsa Spanyol dari Utara sebagaimana yang disebutkan sebelumnya. Akibatnya, Islam tidak dapat memiliki kesempatan untuk berkembang secara penuh dan mendapatkan akarnya di bagian-bagian lain negara kecuali Filipina Selatan dan beberapa daerah pantai. Keadaan ini terus berlanjut sampai Filipina merdeka, kekuasaan secara politik, ekonomi dan sosial didominasi oleh kalangan Non-Muslim yang membuat warga muslim Filipina merasa terancam di negara sendiri dengan kebijakan pemerintah yang mengecilkan arti kelompok-kelompok minoritas.

Kondisi ini tidak membuat warga muslim Filipina tinggal berdiam diri, mereka menyadari keberadaannya sebagai bagian dari warga bangsa yang mempunyai hak yang sama, maka mereka melakukan kegiatan atau aktifitas yang dapat menyadarkan kaum muslim.

Sejak masuknya orang-orang Spanyol ke Filipina, pada 16 Maret $1521 \mathrm{M}$, penduduk pribumi telah mencium adanya maksud lain di balik "ekspedisi ilmiah" Ferdinand de Magellans. Ketika kolonial Spanyol menaklukan wilayah utara dengan mudah dan tanpa perlawanan berarti, tidak demikian halnya dengan wilayah selatan. Mereka justru menemukan penduduk wilayah selatan melakukan perlawanan sangat gigih, berani dan pantang menyerah. Tentara kolonial Spanyol harus bertempur matimatian kilometer demi kilometer untuk mencapai Mindanao-Sulu (kesultanan Sulu takluk pada tahun $1876 \mathrm{M}$ ). Menghabiskan lebih dari 375 tahun masa kolonialisme dengan perang berkelanjutan melawan kaum Muslimin.

Walaupun demikian, kaum Muslimin tidak pernah dapat ditundukan secara total. Selama masa kolonial, Spanyol menerapkan politik devide and rule (pecah belah dan kuasai) serta mision-sacre (misi suci Kristenisasi) terhadap orang-orang Islam. Bahkan orang-orang Islam di-stigmatisasi (julukan terhadap hal-hal yang buruk) sebagai "Moor" (Moro). Artinya orang yang buta huruf, jahat, tidak bertuhan dan huramentados (tukang bunuh). Sejak saat itu julukan Moro melekat pada orang-orang Islam yang 
mendiami kawasan Filipina Selatan tersebut. Tahun 1578 M terjadi perang besar yang melibatkan orang Filipina sendiri. Penduduk pribumi wilayah Utara yang telah dikristenkan dilibatkan dalam ketentaraan kolonial Spanyol, kemudian diadu domba dan disuruh berperang melawan orang-orang Islam di selatan. Terjadilah peperangan antar orang Filipina sendiri dengan mengatasnamakan "misi suci". Dari sinilah kemudian timbul kebencian dan rasa curiga orang-orang Kristen Filipina terhadap Bangsa Moro yang Islam hingga sekarang. Sejarah mencatat, orang Islam pertama yang masuk Kristen akibat politik yang dijalankan kolonial Spanyol ini adalah istri Raja Humabon dari pulau Cebu.

\section{Masa Imperialisme Amerika Serikat}

Sekalipun Spanyol gagal menundukkan Mindanao dan Sulu, Spanyol tetap menganggap kedua wilayah itu merupakan bagian dari teritorialnya. Secara tidak sah dan tak bermoral, Spanyol kemudian menjual Filipina kepada Amerika Serikat seharga US\$ 20 juta pada tahun $1898 \mathrm{M}$ melalui Traktat Paris.

Amerika datang ke Mindanao dengan menampilkan diri sebagai seorang sahabat yang baik dan dapat dipercaya. Inilah karakter musuh-musuh Islam sebenarnya pada abad ini. Hal ini dibuktikan dengan ditandatanganinya Traktat Bates (20 Agustus 1898 M) yang menjanjikan kebebasan beragama, kebebasan mengungkapkan pendapat, kebebasan mendapatkan pendidikan bagi Bangsa Moro. Namun traktat tersebut hanya taktik mengambil hati orang-orang Islam agar tidak memberontak, karena pada saat yang sama Amerika tengah disibukkan dengan pemberontakan kaum revolusioner Filipina Utara pimpinan Emilio Aguinaldo. Terbukti setelah kaum revolusioner kalah pada 1902 M, kebijakan AS di Mindanao dan Sulu bergeser kepada sikap campur tangan langsung dan penjajahan terbuka. Setahun kemudian (1903 M) Mindanao dan Sulu disatukan menjadi wilayah propinsi Moroland dengan alasan untuk memberadabkan (civilizing) rakyat Mindanao dan Sulu.

Periode berikutnya tercatat pertempuran antara kedua belah pihak. Teofisto Guingona, Sr. mencatat antara tahun 1914-1920 rata-rata terjadi 19 kali pertempuran. Tahun 1921-1923, terjadi 21 kali pertempuran. Patut dicatat bahwa selama periode 1898-1902, AS ternyata telah menggunakan waktu tersebut untuk membebaskan tanah serta hutan di wilayah Moro untuk keperluan ekspansi para kapitalis. Bahkan periode 1903-1913 dihabiskan AS untuk memerangi berbagai kelompok perlawanan Bangsa Moro.

Namun Amerika memandang peperangan tak cukup efektif meredam perlawanan Bangsa Moro, Amerika akhirnya menerapkan strategi penjajahan melalui kebijakan pendidikan dan bujukan. Kebijakan ini kemudian disempurnakan oleh orang-orang Amerika sebagai ciri khas penjajahan mereka. Kebijakan pendidikan dan bujukan yang diterapkan Amerika terbukti merupakan strategi yang sangat efektif dalam meredam perlawanan Bangsa Moro. Sebagai hasilnya, kohesitas politik dan kesatuan diantara masyarakat Muslim mulai berantakan dan basis budaya mulai diserang oleh normanorma Barat.

Pada dasarnya kebijakan ini lebih disebabkan keinginan Amerika memasukkan kaum Muslimin ke dalam arus utama masyarakat Filipina di Utara dan mengasimilasi kaum Muslim ke dalam tradisi dan kebiasaan orang-orang Kristen. Seiring dengan berkurangnya kekuasaan politik para Sultan dan berpindahnya kekuasaan secara bertahap ke Manila, pendekatan ini sedikit demi sedikit mengancam tradisi kemandirian. 


\section{Masa Peralihan}

Masa pra-kemerdekaan ditandai dengan masa peralihan kekuasaan dari penjajah Amerika ke pemerintah Kristen Filipina di Utara. Untuk menggabungkan ekonomi Moroland ke dalam sistem kapitalis, diberlakukanlah hukum-hukum tanah warisan jajahan AS yang sangat kapitalistis seperti Land Registration Act No. 496 (November 1902) yang menyatakan keharusan pendaftaran tanah dalam bentuk tertulis, ditandatangani dan di bawah sumpah.

Kemudian Philippine Commission Act No. 718 (4 April 1903) yang menyatakan hibah tanah dari para Sultan, Datu, atau kepala Suku Non-Kristen sebagai tidak sah, jika dilakukan tanpa ada wewenang atau izin dari pemerintah. Demikian juga Public Land Act No. 296 (7 Oktober 1903) yang menyatakan semua tanah yang tidak didaftarkan sesuai dengan Land Registration Act No. 496 sebagai tanah negara, The Mining Law of 1905 yang menyatakan semua tanah negara di Filipina sebagai tanah yang bebas, terbuka untuk eksplorasi, pemilikan dan pembelian oleh WN Filipina dan AS, serta Cadastral Act of 1907 yang membolehkan penduduk setempat (Filipina) yang berpendidikan, dan para spekulan tanah Amerika, yang lebih paham dengan urusan birokrasi, untuk melegalisasi klaim-klaim atas tanah. Pada intinya ketentuan tentang hukum tanah ini merupakan legalisasi penyitaan tanah-tanah kaum Muslimin (tanah adat dan ulayat) oleh pemerintah kolonial AS dan pemerintah Filipina di Utara yang menguntungkan para kapitalis.

Pemberlakukan Quino-Recto Colonialization Act No. 4197 pada 12 Februari 1935 menandai upaya pemerintah Filipina yang lebih agresif untuk membuka tanah dan menjajah Mindanao. Pemerintah mula-mula berkonsentrasi pada pembangunan jalan dan survei-survei tanah negara, sebelum membangun koloni-koloni pertanian yang baru. NLSA - National Land Settlement Administration - didirikan berdasarkan Act No. 441 pada 1939.Di bawah NLSA, tiga pemukiman besar yang menampung ribuan pemukim dari Utara dibangun di propinsi Cotabato Lama.Bahkan seorang senator Manuel L. Quezon pada 1936-1944 gigih mengkampanyekan program pemukiman besar-besaran orang-orang Utara dengan tujuan untuk menghancurkan keragaman (homogenity) dan keunggulan jumlah Bangsa Moro di Mindanao serta berusaha mengintegrasikan mereka ke dalam masyarakat Filipina secara umum.

Kepemilikan tanah yang begitu mudah dan mendapat legalisasi dari pemerintah tersebut mendorong migrasi dan pemukiman besar-besaran orang-orang Utara ke Mindanao. Banyak pemukim yang datang, seperti di Kidapawan, Manguindanao, mengakui bahwa motif utama kedatangan mereka ke Mindanao adalah untuk mendapatkan tanah. Untuk menarik banyak pemukim dari utara ke Mindanao, pemerintah membangun koloni-koloni yang disubsidi lengkap dengan seluruh alat bantu yang diperlukan. Konsep penjajahan melalui koloni ini diteruskan oleh pemerintah Filipina begitu AS hengkang dari negeri tersebut. Sehingga perlahan tapi pasti orangorang Moro menjadi minoritas di tanah mereka.

\section{Masa Pasca Kemerdekaan hingga Sekarang}

Kemerdekaan yang didapatkan Filipina (1946 M) dari Amerika Serikat ternyata tidak memiliki arti khusus bagi Bangsa Moro. Hengkangnya penjajah pertama (Amerika Serikat) dari Filipina ternyata memunculkan penjajah lainnya (pemerintah Filipina). Namun patut dicatat, pada masa ini perjuangan Bangsa Moro memasuki babak baru dengan dibentuknya front perlawanan yang lebih terorganisir dan maju, seperti MIM, Anshar-el-Islam, MNLF, MILF, MNLF-Reformis, BMIF. Namun pada saat yang sama juga sebagai masa terpecahnya kekuatan Bangsa Moro menjadi faksi-faksi yang 
melemahkan perjuangan mereka secara keseluruhan. Pada awal kemerdekaan, pemerintah Filipina disibukkan dengan pemberontakan kaum komunis Hukbalahab dan Hukbong Bayan Laban Sa Hapon. Sehingga tekanan terhadap perlawanan Bangsa Moro dikurangi. Gerombolan komunis Hukbalahab ini awalnya merupakan gerakan rakyat anti penjajahan Jepang. Setelah Jepang menyerah, mereka mengarahkan perlawanannya ke pemerintah Filipina. Pemberontakan ini baru bisa diatasi di masa Ramon Magsaysay, menteri pertahanan pada masa pemerintahan Eipidio Qurino (1948-1953). Tekanan semakin terasa hebat dan berat ketika Ferdinand Marcos berkuasa (1965-1986).

Dibandingkan dengan masa pemerintahan semua presiden Filipina dari Jose Rizal sampai Fidel Ramos maka masa pemerintahan Ferdinand Marcos merupakan masa pemerintahan paling represif bagi Bangsa Moro. Pembentukan Muslim Independent Movement (MIM) pada 1968 dan Moro Liberation Front (MLF) pada 1971 tak bisa dilepaskan dari sikap politik Marcos yang lebih dikenal dengan Presidential Proclamation No. 1081 itu. Perkembangan berikutnya kita semua tahu.MLF sebagai induk perjuangan Bangsa Moro akhirnya terpecah. Pertama, Moro National Liberation Front (MNLF) pimpinan Nurulhaj Misuari yang berideologikan nasionalis-sekuler. Kedua, Moro Islamic Liberation Front (MILF) pimpinan Salamat Hashim, seorang ulama pejuang, yang murni berideologikan Islam dan bercita-cita mendirikan negara Islam di Filipina Selatan. Namun dalam perjalanannya, ternyata MNLF pimpinan Nur Misuari mengalami perpecahan kembali menjadi kelompok MNLF-Reformis pimpinan Dimas Pundato (1981) dan kelompok Abu Sayyaf pimpinan Abdurrazak Janjalani (1993).

Tentu saja perpecahan ini memperlemah perjuangan Bangsa Moro secara keseluruhan dan memperkuat posisi pemerintah Filipina dalam menghadapi Bangsa Moro. Ditandatanganinya perjanjian perdamaian antara Nur Misuari (ketua MNLF) dengan Fidel Ramos (Presiden Filipina) pada 30 Agustus 1996 di Istana Merdeka Jakarta lebih menunjukkan ketidaksepakatan Bangsa Moro dalam menyelesaikan konflik yang telah memasuki 2 dasawarsa itu. Disatu pihak mereka menghendaki diselesaikannya konflik dengan cara diplomatik (diwakili oleh MNLF), sementara pihak lainnya menghendaki perjuangan bersenjata/jihad (diwakili oleh MILF). Semua pihak memandang caranyalah yang paling tepat dan efektif.Namun agaknya Ramos telah memilih salah satu diantara mereka walaupun dengan penuh resiko."Semua orang harus memilih, tidak mungkin memuaskan semua pihak," katanya.Dan jadilah bangsa Moro seperti saat ini, minoritas di negeri sendiri.

Seorang ilmuan Muslim, Asiri Abu Bakar, menunjukkan faktor-faktor bangkitnya warga muslim Filipina:

1. Bertambahnya hubungan ulama dan para pendatang dengan muslim yang terpelajar dari dunia Arab;

2. Bertambahnya jumlah warga Moro yang pergi naik haji;

3. Bertambahnya kesempatan kesempatan melakukan studi di berbagai pusat Islam di seluruh dunia;

4. Partisipasi aktif dalam berbagai pertemuan;

5. Kembalinya ratusan pelajar Muslim dari luar negeri;

6. Semakin banyaknya didirikan madrasah-madrasah di daerah;

7. Kedatanagan para pejabat dari dunia Islam ke Moro;

8. Banyaknya konferensi pers internasional dan peliputan perang yang berlangsung di Mindanao serta kekejaman beberapa personel meliter di wilayah tersebut. 
Kebangkitan tersebut dapat dilihat pula dari,

1. Dibayarkannya tunggakan perang Dunia II kepada beberapa Muslim yang memungkinkan mereka naik haji dan kemudian membangkitkan kesadaran Islam mereka;

2. Bertambahnya perkumpulan dan organisasi Islam yang didukung oleh warga lokal maupun luar negeri;

3. Didirikannya sekolah-sekolah tinggi dan universitas-universitas swasta dan negeri di negara ini yang memberikan kuliah-kuliah dan gelar-gelar dalam studi Islam;

4. Pemberontakan Moro, yang telah mengakibatkan peningkatan kesadaran dan kewaspadaan Muslim.

\section{Faktor Islam Menjadi Agama Minoritas Di Filipina}

Mayoritas penduduk Filipina beragama Katolik, walaupun katolik menjadi agama mayoritas, tetapi di Filipina terdapat tiga ribu masjid, terutama di selatan. Penduduk Filipina sekitar 85.236.900 juta pada tahun 2006 dan setiap tahunnya pertumbuhan penduduknya $1,92 \%$ dengan luas wilayah $300.076 \mathrm{~km}$ terdiri dari 7.107 pulau. Penduduknya terdiri dari beberapa suku yaitu suku Filipino 80\%, Tionghoa 10\%, Indo Arya 5\%, Eropa dan Amerika 2\%, Arab 1\%, suku lain 2\%. Kota Marawi dan Jolo dapat dianggap sebagai pusat keagamaan bagi komunitas muslim. Kitab suci alQur'an telah diterjemahkan oleh dr.Ahmad Domacao Alonto kedalaam bahasa Maranao, bahasa yang paling utama dikalangan muslim kebanyakan muslim di Moro adalah petani dan nelayan. Dijabatan tinggi pemerintah Filipina tidak berarti. Asosiasi islam yang paaling aktif adalah Asosiasi Muslim Filipina (Manila), Ansar al Islam(Kota Marawi), Masyarakat Islam Mualaf (Manila) dan yayasan Islam Sulu (jolo) dan sebagainya. Tahun 1983, Dewan Dakwah Islam Filipina telah dibentuk untuk mempersatukan organisasi-organisasi Muslim di utara dan selatan.

Menurut Majul, ada tiga alasan yang menjadi penyebab sulitnya bangsa Moro berintegerasi secara penuh kepada republik Filipina. Pertama, bangsa Moro sulit menghargai undang-undang Nasional, khususnya yang mengenai hubungan pribadi daan keluarga, karena undang-undang tersebut berasal daari Barat dan Katolik, seperti larangan bercerai dan poligami yang sangat bertentangan dengan hukum Islam yang membolehkannya. Kedua, system sekolah yang menetapkan kurikulum yang sama, bagi setiap anak Filipina disemua daerah, tanpa membedakan perbedaan agama dan kultur, membuat bangsa Moro malas untuk belajar disekolah yang didirikan pemerintah. Mereka menghendaki dalam kurikulum itu adanya perbedaan khusus bagi bangsa Moro, karena adanya perbedaan agama dan kultur.Ketiga, bangsa Moro masih trauma dan kebencian yang mendalam terhadap program perpindahan penduduk yang dilakukan oleh pemerintah Filipina kewilayah mereka di Mindanao, karena program ini telah mengubah posisi mereka dari mayoritas menjadi minoritas hamper disegala bidang kehidupan.

\section{Kesimpulan}

Sejarah masuknya Islam ke wilayah Filipina Selatan, khususnya kepulauan Sulu dan Mindanao pada tahun 1380 M. Seorang tabib dan ulama Arab bernama Karimul Makhdum dan Raja Baguinda tercatat sebagai orang pertama yang menyebarkan ajaran 
Islam di kepulauan tersebut. Menurut catatan sejarah, Raja Baguinda adalah seorang pangeran dari Minangkabau (Sumatra Barat).Ia tiba di kepulauan Sulu sepuluh tahun setelah berhasil mendakwahkan Islam di kepulauan Zamboanga dan Basilan.

Filipina merupakan salah satu Negara yang terdapat di Asia Tenggara yang mayoritas penduduknya beragama Katolik.Islam menjadi agama minoritas.Meskipun Islam menjadi minoritas, terdapat wilayah yang yang menjadikan Islam sebagai agama mayoritas yaitu di Filipina bagian Selatan.Perlu perjuangan untuk menjadikan Islam sebagai agama mayoritas disana. Banyak Negara yang menjajah negera itu seperti Spanyol dan Amerika, selain menajah mereka juga sebagai misionaris yang mempersulit untuk berkembangnya agama Islam.Dengan perjuangan dan persatuan yang tinggi membuat Negara Filipina wilayah selatan penduduknya merdeka dari penjajah dan misionaris.

Proses islamisasi di Filipina pada masa awal adalah melalui tiga hal, yaitu perdagangan, perkawinan dan politik. Diterimanya Islam oleh orang-orang Mindanao, Sulu, Manilad dan sepanjang pesisir pantai kepulauan Filipina tidak terlepas dari ajaran Islam yang dibawa oleh para pedagang tersebut dapat mengakomodasi tradisi lokal.Umat Islam Filipina yang kemudian dikenal dengan bangsa Moro, pada akhirnya menghadapi berbagai hambatan baik pada masa kolonial maupun pasca kemerdekaan. Bila direntang ke belakang, perjuangan bangsa Moro dapat dibagi menjadi tiga fase: Moro berjuang melawan penguasa Spanyol selamalebih dari 375 tahun (1521-1898), Moro berusaha bebas dari kolonialismeAmerika selama 47 tahun (1898-1946), dan Moro melawan pemerintah Filipina (1970-sekarang).

Minimal ada tiga alasan yang menjadi penyebab sulitnya bangsa Moro berintegrasi secara penuh kepada pemerintah Republik Filipina: yaitu: bangsa Moro sulit menerima Undang-Undang Nasional karena jelas undang-undangtersebut berasal dari Barat dan Katolik dan bertentangan dengan ajaran Islam, sistem sekolah yang menetapkan kurikulum yang sama tanpa membedakan perbedaan agama dan kultur membuat bangsa Moro malas untuk belajar di sekolah yang didirikan oleh pemerintah, dan adanya trauma dan kebencian yang mendalam pada bangsa Moro atas program perpindahan penduduk yang dilakukan oleh pemerintah Filipina ke wilayah mereka di Mindanao, karena program ini telah mengubah mereka dari mayoritas menjadi minoritas di segala bidang kehidupan.

\section{Referensi}

Ahm Asy'ari, Akhwan Mukarrom dkk, Pengantar Studi Islam, Surabaya: IAIN Sunan Ampel Press, 2008

Kettani M Ali, Minoritas Muslim di dewasa ini, Jakarta: PT Raja Grafindo Persada, 2005

Muzani Saiful, Pembangunan dan Kebangkitan Islam di Asia Tenggara, Jakarta: LP3ES, 1993

Tebba Sudirman, Perkembangan Mutakhir Hukum Islam di Asia Tenggara: Studi Kasus Hukum Keluarga dan Pengkodifikasinya, Bandung: Mizan,1993

Siti Maryam dkk Sejarah Peradaban Islam, Lkis, 2004

Dr. Hamid A. Rabie, Islam Sebagai Kekuatan International, CV. Rosda Bandung 1985

Hamka, Sejarah Umat Islam, Pustaka Hidayah, 2001

Artikel Sejarah Masuknya Islam di Philipina. oleh Imam nugroho diwww.duiniaislam.com 
http://www.wikipedia.com/

http://adha-coba-coba.blogspot.com/2012/01/islam-di-filipina.html http://www.blogger.com/blogger.g?islam_philipina/

http://dorokabuju.blogspot.com/2007/10/dakwah-islam-di-filipina.html

http://www.duiniaislam.com/sejarah_masuknya_islam_di_philipina/

http://poetrimawardi.blogspot.com/2012/04/ekonomi-islam.html

http://wikipedia/islam_di_filipina_2010/

http://cintailmoe.worpress.com/2008/04/07/sejarah-islam-di-filipina/ 